\title{
The Biodiversity and Ecology of Aquatic Plants at Tasik Chini, Pahang, Malaysia
}

\author{
W.A. Wan Juliana, M.S. Nizam, H.H. Khatijah, Mohd Ekhwan Toriman, \\ Mushrifah Idris, N.A. Nik Norafida, Y.H. Cham and M.N. Nurhanim \\ Faculty of Science and Technology, School of Environmental and Natural Resource Science, \\ Universiti Kebangsaan Malaysia, 43600 UKM Bangi, Selangor Darul Ehsan, Malaysia
}

\begin{abstract}
This study determines the distribution, abundance and relationships between Nelumbo nucifera and Cabomba furcata as well as to map out the distribution of the two most dominant aquatic plant species at Tasik Chini, Pahang, Malaysia. Ten sampling stations were selected and ten quadrats of $3 \times 3 \mathrm{~m}$ were established at each sampling station on 2009 to July 2010. Data were analyzed to determine percentage cover of the two species, Nelumbo nucifera and Cabomba furcata in each quadrats and the biomass (dry weight) of each species was estimated. The water quality parameters using YSI multi probe in each station were also measured. Study on the mapping of distribution for Lepironia articulata and Pandanus helicopus includes all the twelve water bodies (namely Laut 1-12) in Tasik Chini. At every station, five coordinate sampling points for Global Positioning System (GPS) were recorded. At the same coordinate points recorded the depth of water were measured using a staff gauge with a maximum length of $5 \mathrm{~m}$. The image of Tasik Chini dated 10 September, 2007 captured by spot- 5 was obtained from Malaysia Centre for Remote Sensing (MACRES). Image processing was done in the laboratory using ERDAS Imagine 9.1 and ArcGis 9.2 software. The result indicates that a total of 73 from 100 quadrats showed the occurrence of Cabomba furcata whilst the Nelumbo nucifera occurred in only three quadrates. Estimation of percentage cover of Cabomba furcata revealed $95.1 \%$ cover whilst the Nelumbo nucifera indicated a $4.9 \%$ overall cover. The total dry weight of Cabomba furcata was $7892.5 \mathrm{~g}$ whereas the Nelumbo nucifera indicated a dry weight of $237 \mathrm{~g}$. The relationship between the two species with the water quality parameters were analyzed using the Redundancy Analysis (RDA). The RDA indicated that the parameter of $\mathrm{NH}_{4}-\mathrm{N}, \mathrm{PO}_{4}^{2}$, TSS, BOD and COD influenced the distribution and abundance of Cabomba furcata however, the distribution and abundance of Nelumbo nucifera were influenced by parameters of namely $\mathrm{NH} 4-\mathrm{N}, \mathrm{SO}_{4}{ }^{2}, \mathrm{NO}_{3}$, temperature and $\mathrm{DO}$. This study clearly shows that the water parameters influence the distribution and abundance of the two populations of Cabomba furcata and Nelumbo nucifera. From the image processing both species Lepironia articulata and Pandanus helicopus appear in the whole lake, except Laut 4 and 5. Lepironia articulata was found mostly at the shallow waters where as Pandanus helicopus was found at both shallow and deep areas.
\end{abstract}

Key words: Tasik Chini, biomass, water quality, redundancy analysis, aquatic plant, Nelumbo nucifera, Cabomba furcate, Malaysia

\section{INTRODUCTION}

Tasik Chini is known as the 2nd largest natural asfreshwater lake in Peninsular Malaysia, consist of twelve other smaller lakes which flow trough Sungai Chini to Sungai Pahang. The lake covers an area of 202 ha and is surrounded by a total of 4975 ha of tropical forests known as Tasik Chini forest reserves (Kutty et al., 2005; Toriman et al., 2010). The natural environment in Tasik Chini that includes rivers, lake, swamps, lowland and hill forests as well as the indigenous people form a unique ecosystem for eco-tourism purposes. Recent situation, the decline population of Nelumbo nucifera (water-lily) seem reducing the eco-tourism factors and it is believe that was it caused by the rapid spread of a macrophyte called Cabomba furcata. The other most dominant macrophyte is the emergent macrophyte, Lepironia articulata and Pandanus helicopus (Hussin, 2005; Dan Ahmad Badri Mohamad, 1992) that are happened to be spread most to the lake. Since, the rapid growth of the C. furcata and the decline of population of $N$. nucifera as well as the most spread of L. articulata and $P$. helicopus is stillongoing, a study was conducted to determine the abundance of C. furcata and $N$. nucifera

Corresponding Author: W.A. Wan Juliana, School of Environmental and Natural Resource Science, Faculty of Science and Technology, Universiti Kebangsaan Malaysia, 43600 UKM Bangi, Selangor Darul Ehsan, Malaysia 
and to evaluate relationship and factors that influence the abundance of both population. The distribution of the two most dominant macrophyte species, L. articulata and $P$. helicopus were also mapped in relation to the water depth of the Tasik Chini.

\section{MATERIALS AND METHODS}

Study site and sampling procedure: A total of ten sampling stations were chosen at Tasik Chini, Pahang (Table 1 and Fig. 1). Ten quadrats of $3 \times 3 \mathrm{~m}$ were establish along a line transect of $150 \mathrm{~m}$ with $15 \mathrm{~m}$ intervals for the C. furcata and N. nucifera study. Altogether, there were 100 quadrats established for this surveyed. Percentage coverage of both species was estimated in all quadrats using crude eye observation. Subsequently, the species that occurred in the quadrats was harvested for determination of its biomass. Harvesting was only conducted on those clumps or individuals that emerged above the water surface.

The harvested samples were kept in polythene bags and brought to the laboratory for drying. All samples were dried in the oven at $70^{\circ} \mathrm{C}$ until constant weights were obtained. Mapping of the distribution of Lepironia and Pandanus was conducted based on field observation and spot-5 image processing in the lab. All the twelve water bodies in Tasik Chini which are called Laut by the local are included in this research (each Laut one station). At every station, five coordinate of sampling points were recorded. The depth of water was mebbasured using a staff gauge with a maximum length of $5 \mathrm{~m}$.
Water quality parameters: Data on water quality parameters were obtained from the Tasik Chini water quality group who conducted water quality survey at the similar sampling locations (Toriman et al., 2010). Water quality parameters used in this study are temperature, $\mathrm{pH}$, conductivity, Dissolved Oxygen (DO), Biochemical Oxygen Demand (BOD), Chemical Oxygen Demand (COD), Total Suspended Solids (TSS), ammonium nitrogen $\left(\mathrm{NH}_{4}-\mathrm{N}\right)$, Nitrate $\left(\mathrm{NO}_{3}{ }^{-}\right)$, phosphate $\left(\mathrm{PO}_{4}{ }^{2-}\right)$ and sulfate $\left(\mathrm{SO}_{4}^{2-}\right)$. Detailed methods on the water analysis can be referred in Shuhaimi-Othman et al. (2007).

Data analysis: Abundance analysis was based on biomass (dry weight) of both species in each quadrat at all sampling locations. Estimation of percentage cover for each sampling station was obtained by calculating average cover of ten quadrats at each sampling station. Relationships between species and water quality data were analyzed using multivariate techniques of

Table 1: Ten sampling stations and the coordinates of each station

\begin{tabular}{|c|c|c|}
\hline Station no. & Name & Coordinates \\
\hline S1 & Laut Gumum & $\mathrm{N}^{\circ} 3^{\circ} 26.021^{\prime} \mathrm{E} 102^{\circ} 55.745^{\prime}$ \\
\hline S2 & Laut Pulau Balai & $\mathrm{N}^{\circ} 3^{\circ} 25.951^{\prime} \mathrm{E} 102^{\circ} 55.462^{\prime}$ \\
\hline S3 & Laut Chenahan & $\mathrm{N}^{\circ} 3^{\circ} 26.249^{\prime} \mathrm{E} 102^{\circ} 55.092^{\prime}$ \\
\hline S4 & Laut Gunung Jerating & $\mathrm{N}^{\circ} 3^{\circ} 26.081^{\prime} \mathrm{E} 102^{\circ} 54.677^{\prime}$ \\
\hline S5 & Laut Tanjung Jerankung & $\mathrm{N}^{\circ} 3^{\circ} 26.423^{\prime} \mathrm{E} 102^{\circ} 54.828^{\prime}$ \\
\hline S6 & Laut Mempitih & $\mathrm{N}^{\circ} 3^{\circ} 25.833^{\prime} \mathrm{E} 102^{\circ} 54.510^{\prime}$ \\
\hline S7 & Laut Kenawar & $\mathrm{N}^{\circ} 3^{\circ} 25.633^{\prime} \mathrm{E} 102^{\circ} 54.119^{\prime}$ \\
\hline S8 & Laut Seradong & $\mathrm{N}^{\circ} 3^{\circ} 25.614^{\prime} \mathrm{E} 102^{\circ} 54.636^{\prime}$ \\
\hline S9 & Laut Batu Buruk & $\mathrm{N}^{\circ} 3^{\circ} 24.803^{\prime} \mathrm{E} 102^{\circ} 54.663^{\prime}$ \\
\hline$\underline{\mathrm{S} 10}$ & Laut Melai & $\mathrm{N}^{\circ} 3^{\circ} 25.726^{\prime} \mathrm{E} 102^{\circ} 55.082^{\prime}$ \\
\hline
\end{tabular}

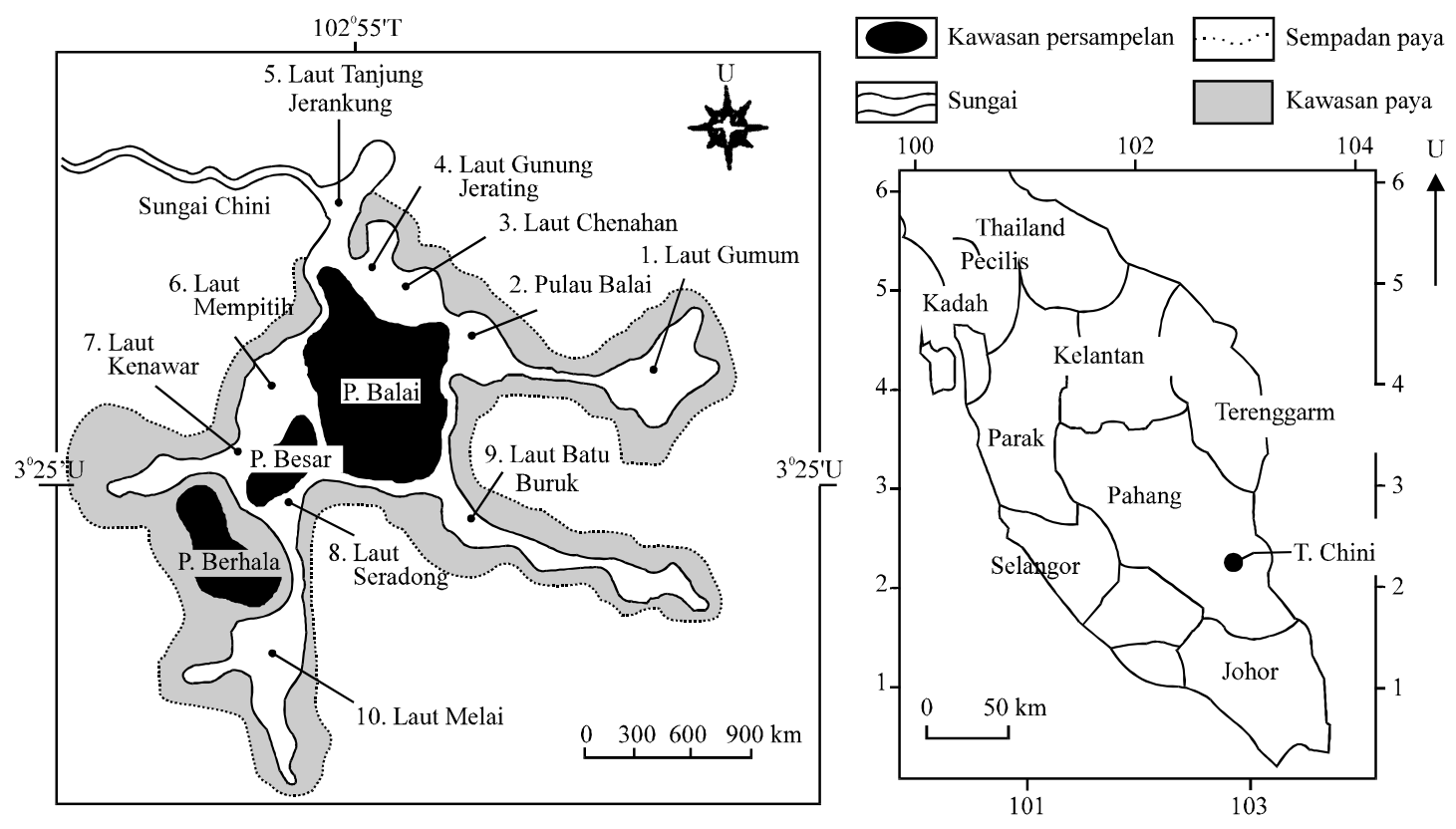

Fig. 1: Sampling location in Tasik Chini 
Redundancy Analysis (RDA) in CANOCO program Version 4 (Ter Braak and Smilauer, 1998). Prior to conducting the RDA, Detrended Correspondence Analysis (DCA) was performed to verify the length of the species gradients extracted from the data for the purpose of deciding whether, a linear or unimodal analysis should be carried out. The DCA showed that the value of the species gradient length was $<3$ hence, a linear analysis was suitable. Given that the analysis was to determine relationships between species and environmental factors, a direct gradient analysis of RDA was appropriate. The RDA is a constrained linear method from canonical ordination which allows interpretation of relationship between species and environmental factors be carried out. The image of Tasik Chini dated 10. 9. 2007 captured by spot-5 is obtained from Malaysia Centre for Remote Sensing (MACRES). Image processing is done in the laboratory using ERDAS imagine 9.1 and ArcGIS 9.2 software.

\section{RESULTS AND DISCUSSION}

\section{Distribution and coverage of Nelumbo nucifera and} Cabomba furcata: Frequency of occurrence of both species in all quadrats at all sampling stations were used to describe distribution of the species at Tasik Chini. The study showed that C. furcata dominated most area of the lake compared to $N$. nucifera whereby the former occurred in 73 quadrats that reflects frequency of $73 \%$ whereas, the latter was recorded in only three quadrats (3\%) out of 100 quadrats established (Table 2). Table 2 also shows that the C. furcata occurred at all sampling stations with various frequency of occurrence whilst the
$N$. nucifera was only observed at Laut Melai sampling station (station 10). Figure 2 shows estimation of percentage cover for both species at each sampling station. The coverage of C. furcata at the station 7 (Laut Kenawar) was the highest with percentage cover of $87.5 \%$ whilst the lowest coverage of this species was at station 9 (Laut Batu Buruk) of $6 \%$.

In contrast, $N$. nucifera that was only found at station 10 (Laut Melai), showed only 19\% coverage and no species cover was observed at the other nine sampling stations. In terms of average cover of the study quadrats, $95.1 \%$ of all the quadrat area was dominated by the C. furcata whereas only $4.9 \%$ of the area was populated by the $N$. nucifera.

It should be highlighted that the colony of C. furcata was never been observed in 1980 's; a studied by DARA reported the $N$. nucifera as the most dominant aquatic macrophyte at Tasik Chini, coexisted

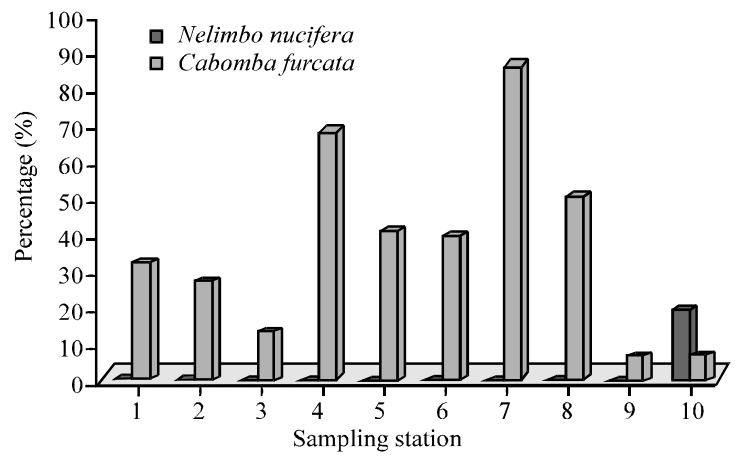

Fig. 2: Estimation of percentage species cover at each sampling station

Table 2: Frequency of occurrence of C. furcata and $N$. mucifera in all quadrats at selected sampling stations in Tasik Chini

\begin{tabular}{|c|c|c|c|c|c|c|c|c|c|c|c|c|}
\hline \multirow{2}{*}{$\begin{array}{l}\text { Sampling } \\
\text { stations }\end{array}$} & \multirow[b]{2}{*}{ Species } & \multicolumn{10}{|c|}{ Quadrats } & \multirow[b]{2}{*}{ Frequency $(\%)$} \\
\hline & & 1 & 2 & 3 & 4 & 5 & 6 & 7 & 8 & 9 & 10 & \\
\hline \multirow[t]{2}{*}{$\mathrm{S} 1$} & N. nucifera & - & - & - & - & - & - & - & - & - & - & 0 \\
\hline & C. furcata & + & + & + & + & + & + & + & + & + & + & 100 \\
\hline \multirow[t]{2}{*}{$\mathrm{S} 2$} & N. nucifera & - & - & - & - & - & - & - & - & - & - & 0 \\
\hline & C. furcata & + & + & + & + & - & - & - & - & - & - & 40 \\
\hline \multirow[t]{2}{*}{ S3 } & N. mucifera & - & - & - & - & - & - & - & - & - & - & 0 \\
\hline & C. furcata & + & + & + & - & - & - & - & - & - & - & 30 \\
\hline \multirow[t]{2}{*}{$\mathrm{S} 4$} & N. nucifera & - & - & - & - & - & - & - & - & - & - & 0 \\
\hline & C. furcata & + & + & + & + & + & + & + & + & + & + & 100 \\
\hline \multirow[t]{2}{*}{ S5 } & N. nucifera & - & - & - & - & - & - & - & - & - & - & 0 \\
\hline & C. furcata & + & + & + & + & + & + & + & + & + & + & 100 \\
\hline \multirow[t]{2}{*}{ S6 } & N. nucifera & - & - & - & - & - & - & - & - & - & - & 0 \\
\hline & C. furcata & + & + & + & + & + & + & + & + & + & + & 100 \\
\hline \multirow[t]{2}{*}{ S7 } & N. nucifera & - & - & - & - & - & - & - & - & - & - & 0 \\
\hline & C. furcata & + & + & + & + & + & + & + & + & + & + & 100 \\
\hline \multirow[t]{2}{*}{ S8 } & N. nucifera & - & - & - & - & - & - & - & - & - & - & 0 \\
\hline & C. furcata & + & + & + & + & + & + & + & + & + & + & 80 \\
\hline \multirow[t]{2}{*}{ S9 } & N. nucifera & - & - & - & - & - & - & - & - & - & - & 0 \\
\hline & C. fircata & + & + & + & + & - & - & - & - & - & - & 40 \\
\hline \multirow[t]{2}{*}{$\mathrm{S} 10$} & N. mucifera & - & + & + & + & - & - & - & - & - & - & 30 \\
\hline & C. furcata & + & + & + & + & - & - & - & - & - & - & 40 \\
\hline
\end{tabular}


with the 2nd most dominant species of Pandanus helicopus. However in 1990 's, the presence of the colony C. furcata was noticed in several areas such as at Laut Batu Buruk, Laut Labuh and Laut Jemberau. Compared with the current study, the spread of this colony is tremendous whereby most lake areas of Tasik Chini are covered by this species.

Dry weight: The total dry weight of $C$. furcata at all sampling station was $7828.8 \mathrm{~g}$ in which the station 7 (Laut Kenawar) recorded the highest dry weight of $2480.5 \mathrm{~g}$. On the other hand, the total dry weight of $N$. nucifera that was only found at station 10 was far lower with an estimation of $237 \mathrm{~g}$. Table 3 shows the dry weight of both species at all sampling stations.

The results clearly show that besides the observation on species coverage, data on dry weight (biomass) have obviously indicated that the abundance of C. furcata is extremely high compared to $N$. nucifera. This phenomenon may partly due to the factor that the C. furcata is having high growth rate where the domination of the species could occur easily.

Water quality parameters: Water quality data were based on the study conducted by Shuhaimi-Othman et al. (2007) (Table 4). Table 4 shows that water $\mathrm{pH}$ values are in the

Table 3: Total dry weight of C. furcata and N. nucifera at sampling stations in Tasik Chini

\begin{tabular}{lcc}
\hline \multicolumn{3}{c}{ Total dry weight (g) } \\
Sampling stations & C. furcata & N. nucifera \\
\hline 1 (Laut Gumum) & 600.4 & 0.0 \\
2 (Laut Pulau Balai) & 551.7 & 0.0 \\
3 (Laut Chenahan) & 145.2 & 0.0 \\
4 (Laut Gunung Jerating) & 1432.8 & 0.0 \\
5 (Laut Tanjung Jerankung) & 574.2 & 0.0 \\
6 (Laut Mempitih) & 683.2 & 0.0 \\
7 (Laut Kenawar) & 2480.5 & 0.0 \\
8 (Laut Seradong) & 992.0 & 0.0 \\
9 (Laut Batu Buruk) & 156.1 & 0.0 \\
10 (Laut Melai) & 212.7 & 237.0 \\
Total & 7828.8 & 237.0 \\
\hline
\end{tabular}

range of 6.06-6.67 where the station 9 (Laut Batu Buruk) had the highest $\mathrm{pH}$ value of 6.67 whilst the lowest was recorded at station 5 of 6.06 . The station 9 was also recorded to have the highest water temperature and conductivity of $30.35^{\circ} \mathrm{C}$ and $29.98 \mu \mathrm{Scm}^{-1}$, respectively. Further, the station 1 (Laut Gumum) recorded the highest Dissolved Oxygen (DO), Biological Oxygen Demand (BOD) and Chemical Oxygen Demand (COD) with values of $6.31,1.95$ and $19.37 \mathrm{mg} \mathrm{L}^{-1}$, respectively. The highest Total Suspended Solid (TSS) was recorded at station 4 (Laut Gunung Jerating) of $21.71 \mathrm{mg} \mathrm{L}^{-1}$ whilst the station 10 (Laut Melai) showed the lowest TSS of $4.96 \mathrm{mg} \mathrm{L}^{-1}$. Moreover, the station 4 had highest ammonia nitrogen $\left(\mathrm{NH}_{3}-\mathrm{N}\right)$ value of $0.289 \mathrm{mg} \mathrm{L}^{-1}$ while the station 10 (Laut Melai) recorded the highest nitrate $\left(\mathrm{NO}_{3}{ }^{-}\right)$content of $0.24 \mathrm{mg} \mathrm{L}^{-1}$. The highest phosphate concentration was recorded at the station 1 (Laut Gumum) of $0.082 \mathrm{mg} \mathrm{L}^{-1}$ and the highest sulphate content was recorded at the station 9 (Laut Batu Buruk) and station 10 (Laut Melai) with value of $1.181 \mathrm{mg} \mathrm{L}^{-1}$.

Relationships between water quality parameters and the presence of $N$. nucifera and $C$. furcata: Redundancy Analysis (RDA) was conducted to observe relationships between water quality parameter and the presence of N. nucifera and C. furcata at Tasik Chini. Figure 3 shows the ordination diagram of RDA where the numbered points represent the sampling locations and the arrows represent the vectors of water quality parameters and the species of $N$. nucifera and C. furcata.

Figure 3 obviously indicates that the arrow vectors for both $N$. nucifera and C. furcata are pointing at different directions as well as distantly situated from each other. Based on the survey data, it is clear that both species do not occur together at all sampling locations except at the station 10 (Laut Melai) where N. nucifera was present in three sampling quadrats. From this analysis, it is apparent that the two species are located closely to different water parameter vectors which reflect

Table 4: Water quality parameters at sampling stations based on Shuhaimi-Othman et al. (2007)

\begin{tabular}{|c|c|c|c|c|c|c|c|c|c|c|}
\hline \multirow[b]{2}{*}{ Parameters } & \multicolumn{10}{|c|}{ Sampling stations } \\
\hline & 1 & 2 & 3 & 4 & 5 & 6 & 7 & 8 & 9 & 10 \\
\hline $\mathrm{pH}$ & 6.530 & 6.380 & 6.480 & 6.320 & 6.060 & 6.620 & 6.630 & 6.650 & 6.670 & 6.540 \\
\hline Temperature & 29.380 & 29.40 & 29.490 & 29.150 & 29.030 & 29.830 & 29.960 & 29.870 & 30.350 & 29.410 \\
\hline Conductivity & 23.970 & 24.090 & 22.750 & 23.500 & 21.830 & 19.410 & 20.100 & 26.530 & 29.980 & 26.660 \\
\hline DO & 6.310 & 5.650 & 5.980 & 5.130 & 4.090 & 5.920 & 5.880 & 5.860 & 6.120 & 5.740 \\
\hline BOD & 1.950 & 1.680 & 1.690 & 1.610 & 1.440 & 1.590 & 1.700 & 1.380 & 1.080 & 1.770 \\
\hline COD & 19.370 & 17.570 & 16.730 & 15.810 & 14.790 & 18.680 & 18.310 & 17.870 & 12.930 & 18.630 \\
\hline TSS & 11.780 & 9.450 & 11.280 & 21.710 & 13.440 & 7.890 & 7.960 & 6.180 & 12.930 & 4.960 \\
\hline $\mathrm{NH}_{3}-\mathrm{N}$ & 0.217 & 0.176 & 0.196 & 0.289 & 0.212 & 0.153 & 0.148 & 0.165 & 0.084 & 0.143 \\
\hline $\mathrm{NO}_{3}^{-}$ & 0.142 & 0.221 & 0.226 & 0.206 & 0.120 & 0.073 & 0.123 & 0.072 & 0.186 & 0.240 \\
\hline $\mathrm{PO}_{4}^{3-}$ & 0.082 & 0.058 & 0.068 & 0.062 & 0.061 & 0.062 & 0.066 & 0.059 & 0.058 & 0.062 \\
\hline $\mathrm{SO}_{4}^{2-}$ & 0.181 & 0.292 & 0.250 & 0.236 & 0.306 & 0.389 & 0.264 & 1.097 & 1.181 & 1.181 \\
\hline
\end{tabular}

Temperature $\left({ }^{\circ} \mathrm{C}\right)$; Conductivity $\left(\mu \mathrm{Scm}^{-1}\right)$; DO: Dissolved Oxygen ( $\left.\mathrm{mg} \mathrm{L}^{-1}\right)$; BOD: Biological Oxygen Demand (mg L ${ }^{-1}$ ); COD: Chemical Oxygen Demand (mg L $\left.{ }^{-1}\right)$; TSS: Total Suspended Solid ( $\left.\mathrm{mg} \mathrm{L}^{-1}\right) ; \mathrm{NH}_{3}-\mathrm{N}\left(\mathrm{mg} \mathrm{L}^{-1}\right) ; \mathrm{NO}_{3}^{-}\left(\mathrm{mg} \mathrm{L}^{-1}\right) ; \mathrm{PO}_{4}{ }^{3-}\left(\mathrm{mg} \mathrm{L}^{-1}\right) ; \mathrm{SO}_{4}{ }^{2-}\left(\mathrm{mg} \mathrm{L}^{-1}\right)$ 


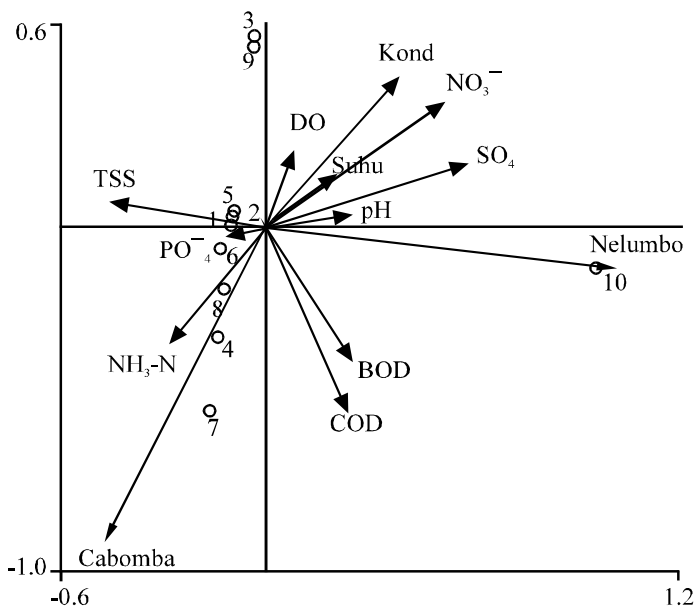

Fig. 3: RDA ordination diagram demonstrating the relationships between water quality parameters and the abundance of $N$. nucifera and C. furcata (No. 1-10: sampling stations)

the preference of water quality for both species at their habitats. Figure 3 shows that the ammonia nitrogen $\left(\mathrm{NH}_{3}-\mathrm{N}\right)$ vector is closely situated next to the C. furcata vector. This shows that the occurrence of C. furcata at the study location is highly influenced by the presence of ammonia nitrogen. Based on this, C. furcata can be considered as in favour of high ammonia concentration for its survival while this is a different case for $N$. nucifera which distantly located from the ammonia vector, inferring the species favours to a habitat with a low nitrogen level. It has been suggested by Tilman and Wedin (1991) that a species that is adapted to a low nitrogen level habitat would finally be excluded by other species that has high nitrogen dependency. The scenario of present study at Tasik Chini seems in accordance with the suggestion of Tilman and Wedin (1991) where N. nucifera gradually being excluded by C.furcata.

In addition, Morecroft et al. (1994) and Aulio and Salin (1982) showed that the increase in ammonium content on semi-natural grassland communities in the United Kingdom had decreased the population of a moss species, Rhytidiadelphus squarrosus that favours low nitrogen content; the study clearly showed that the increase of nitrogen content in a vegetation community of the natural habitats would decline the population survival of certain species because of eutrophication.

Figure 3 also indicates that the other water quality parameters such as phosphate $\left(\mathrm{PO}_{4}{ }^{2-}\right)$, Total Suspended Solid (TSS), Biochemical Oxygen Demand (BOD) and Chemical Oxygen Demand (COD) also influence the occurrence of $C$. furcata. The vector of $N$. nucifera positioned closely to the $\mathrm{pH}$, sulphate $\left(\mathrm{SO}_{4}{ }^{2-}\right)$, nitrate
$\left(\mathrm{NO}_{3}{ }^{-}\right)$, temperature, conductivity and Dissolved Oxygen (DO) vectors. The closest $\mathrm{pH}$ vector to this species reflects the influence of water $\mathrm{pH}$ on the occurrence of the species at the study location. Nevertheless, since the $\mathrm{pH}$ values between sampling locations did not vary greatly thus, the influence of the $\mathrm{pH}$ parameter cannot be seen clearly. According to Chapeon (1992), suitable pH level for a lake ecosystem is between $\mathrm{pH} 4.5-6.5$ and $\mathrm{pH}$ levels at sampling stations were within this range. It is apparent that the vector for $N$. nucifera is pointing at opposite direction of the vector Total Suspended Solid (TSS).

This scenario infers that the abundance of $N$. nucifera has a negative correlation with the total suspended solid present in the water body. Among main causes of the increase in total suspended solid are forest clearings for developments and agriculture (Toriman et al., 2009). DARA reported the increase of TSS in the water body at Tasik Chini was due to forest exploitations by the locals for agricultural activities, rubber plantations and oil palm plantations.

As observed, all sampling stations that are positioned close to the TSS vector (stations 1, 2, 5,6 and 8; Fig. 3) have turbid water and there was absolutely no trace of $N$. nucifera population. Moreover, the abundance of $N$. nucifera has a negative correlation with the amount of phosphate and ammonia nitrogen in the lake as the vectors for both water quality parameters are situated far from the $N$. nucifera vector.

The C. furcata dominated sampling stations such as stations 1-8 are influenced by the total suspended solid, phosphate and ammonia nitrogen parameters while the station 10 has obviously negative correlation with those parameters. Field observation also revealed that the water at the station 10 (Laut Melai) was clearer than other stations, of which $N$. nucifera population was recorded in three sampling quadrats at this station. This study clearly indicates that both $C$. furcata and $N$. nucifera have different environmental requirements and it is evident that the water quality factors play essential roles in influencing population distributions of both species at the study location. It can be concluded that the $N$. nucifera population is more suitable to develop in undisturbed surroundings where the water is clean while the C. furcata dominates environments of low water quality.

Distribution and coverage of Lepironia articulata dan Pandanus helicopus: Occurrence of both species in all quadrats at all sampling stations was used to describe distribution of L. articulata and P. helicopus at Tasik Chini. The study showed that L. articulata and $P$. helicopus dominated most area of the lake. Apparently, 


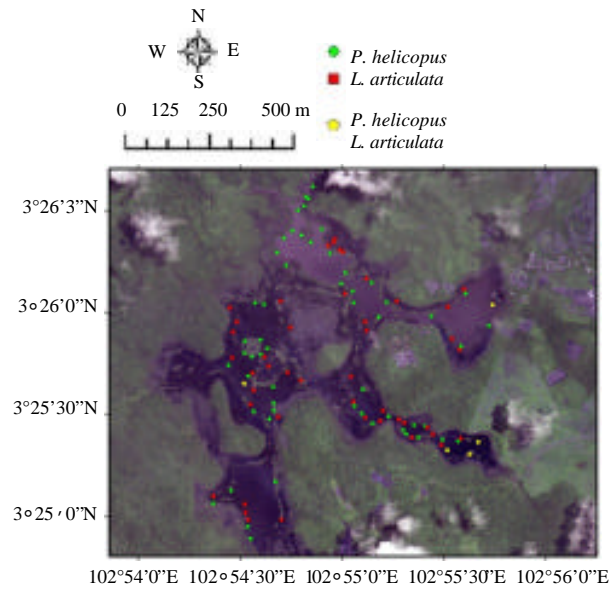

Fig. 4: Distribution of Lepironia articulata dan Pandanus helicopus in all quadrats at selected sampling stations in Tasik Chini

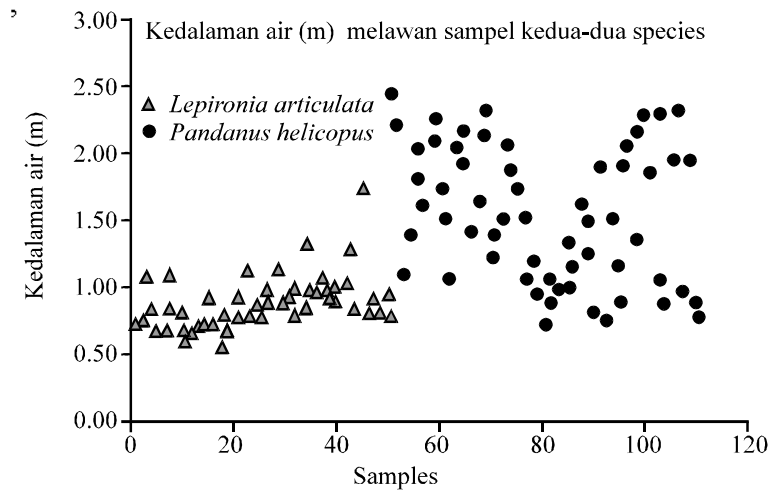

Fig. 5: Water depth against the sample of Lepironia articulata and Pandanus helicopus

there was no individual of L. articulata at station 4 and 5 but it was distributed dominantly at station 10 and 11 . As for the $P$. helicopus, it was dominant at station 4, 5, 7 and also half of the station 6 (Fig. 4).

Influence of water depth towards distribution of Lepironia articulata dan Pandanus helicopus: From the data obtained both species L. articulata and $P$. helicopus were influenced by the water depth. Even though both species occurred at almost all station (except station 4 and 5 for L. articulata) but L. articulata was found at almost shallow area where as $P$. helicopus was found grew at both shallow and depth areas. Figure 5 shows the water depth against the sample collected.

\section{CONCLUSION}

In this study, it can be stated that Tasik Chini is still rich in biodiversity. Over the last 15 years, the relationship between biodiversity and ecosystem functioning in Tasik Chini has emerged as a central issue in lake conservation and restoration. Human environmental impacts include the destruction and fragmentation of natural habitats, pollution, climate change, over exploitation of biological resources, homogenization of biota and biodiversity loss (Bosserman, 1981; Chiras, 2001). These impacts affect species and ecosystems indistinctly in Tasik Chini.

In this regards, the present of Nelumbo nucifera and Cabomba furcate in which is considered as two most dominant aquatic plant species were mapped. General vegetation patterns as well as dry weight (biomass) have been identified as have the general interrelationships that exist between the water quality and plant distribution. In particular, the importance of the period of inundation as well as water depth has been identified influence the distribution and abundance of the two populations of Cabomba furcata and Nelumbo nucifera. Given the extent of change in these environments.

\section{RECOMMENDATIONS}

It is recommended that further specific investigations must be undertaken to identify the importance of such adaptations, especially in relation to management actions that may result in further change.

\section{ACKNOWLEDGEMENTS}

The study was made possible through the funding by the UKM-ST-01-FRGS0034-2006. The researchers thank En. Sani bin Miran for his assistance in the field throughout the study. Special thanks also to Tasik Chini Research Centre, PPTC for providing general assistance.

\section{REFERENCES}

Aulio, K. and M. Salin, 1982. Enrichment of Cu, Zn, Mn and $\mathrm{Fe}$ in five species pondweeds (Potamogeton spp). Bull. Environ. Cont. Toxic., 29: 320-325.

Bosserman, R.W., 1981. Elemental composition of aquatic plants from Okefenokee swamp. Freshwater Ecol., 1: 307-319.

Chapeon, D., 1992. Water Quality Assessment: A Guide to the use of Biota, Sediments and Water in Environmental Monitoring. Chapman and Hall Ltd., London, pp: 58-100.

Chiras, D.D., 2001. Environmental Science: Creating a Sustainable Future. Jones and Bartlett Publishers, Inc., Sudbury, MA, USA.

Dan Ahmad Badri Mohamad, A.I., 1992. Ekologi Air Tawar. Dewan Bahasa dan Pustaka, Kuala Lumpur. 
Hussin, K.H., 2005. Aquatic Plants and their Anatomical Adaptations. In: Sumber Asli Tasik Chini, Idris, M., K.H. dan Abdul Latiff Mohamad (Eds.). Universiti Kebangsaan Malaysia, Bangi, pp: 69.

Kutty, A.A., M. Idris, S. Othman and K. Budin, 2005. Kajian Kepekatan Logam Berat di Dalam Air Dan Tumbuhan Akuatik. In: Sumber Asli Tasik Chini, Idris, M., K.H. dan Abdul Latiff Mohamad (Eds.). Universiti Kebangsaan Malaysia, Bangi, pp: 36-44.

Morecroft, M.D., E.K. Sellers and J.A. Lee, 1994. An experimental investigation into the effects of atmospheric nitrogen deposition on two semi-natural grassland. J. Ecol., 82: 475-483.

Shuhaimi-Othman, M., E.C. Lim and M. Idris, 2007. Water quality changes in Chini Lake, Pahang, West Malaysia. Environ. Monitoring Assess., 131: 279-292.
Ter Braak, C.J.F. and P. Smilauer, 1998. CANOCO Reference Manual and User's Guide to Canoco for Windows: Software for Canonical Community Ordination. Version 4, Microcomputer Power, Ithaca, New York, USA., pp: 351.

Tilman, D. and D. Wedin, 1991. Dynamics of nitrogen competition between successional grasses. Ecology, 72: 1038-1049.

Toriman, M.E., M. Idris and N.R. Jamil, 2010. Monitoring spatial variability of lowland dipterocarp forest in Lake Chini catchment, Malaysia. World Applied Sci. J., 8: 54-60.

Toriman, M.E., M.K.A. Kamarudin, M.H. Idris, N.R. Jamil, M.B. Gazim and N.A.A. Aziz, 2009. Sediment concentration and load analyses at Chini river, Pekan, Pahang Malaysia. Res. J. Earth Sci., 1: 43-50. 